\title{
DESIGN OF SUPERIOR SCHOOL PARADIGM AND MODEL ACCEPTANCE OF NEW STUDENT THROUGH SCHOOL REFORM
}

\author{
Taufiq Harris \\ Gresik University, Indonesia \\ zananharris@yahoo.com
}

\begin{abstract}
The movement of education quality improvement through school reform by creating a superior school paradigm design and new student acceptance model (PPDB) has a strategic position to condition the school to keep abreast of developments and changing times, so as to have the ability to adjust the new paradigm in the global era, The role to serve education equally and fairly in all levels of society. Thus the quantity and quality of Indonesian human resources as the key to success in creating a glorious national development.
\end{abstract}

Keywords: school reform, superior school paradigm, new student acceptance model

\section{INTRODUCTION}

Now, take a bowl of sand and an emerald grain. Then look, notice the glistening emeralds, whose eyes are not enamored of them. It is a bowl of sand that is the parable of the countries that exist in the world, while emerald is the land of Indonesia - the expression is a gratitude to God Almighty, because it has been endowed with all the means and convenience to obtain happiness in prosperity and prosperity. Notice, almost everything that is given to other nations in this world is given to us, and not everything given to us is given to them. And it can not be denied that Indonesia is a country that is second to none in the world.

Utilizing sparkling emeralds and various resources available, in order to realize the vision of national development, namely to make the nation of Indonesia as an independent nation, prosperous, just and prosperous, would require the support of qualified human resources - this is only obtained through quality education.

Education is the key to realizing the vision of national development, but it can not be denied, in today's globalized era, education is a complex issue and does not seem to be completely resolved. It is understandable, because the global influence, so that increasing aspects and elements of a more complex in the world of education. Many experts try to assemble, summarize the theory, but still can not provide satisfactory answers for various parties. There never seems to be a satisfactory theory of education.

Currently, 72 Years, the Indonesian people enjoy independence - the condition of education in Indonesia is still very apprehensive in terms of the quality of global challenges. According to a report from the United Nations Development Programe or UNDP 2003, HDI Indonesia ranked 112 out of 175 countries with the Index of 0.682 (0-1 scale), below South Africa which came in 111th place, and Vietnam ranked 109. This position dropped 10 points When compared with 2001. A slight improvement in the 2007-2008 UNDP 2007-08 value of HDI 0.728 is ranked 107th out of 177 countries. And ironically, in the report of UNDP 2015, the value of HDI Indonesia of 0.689 this value put Indonesia in rank 113 of 188 countries. While the results of the study PISA (Program for International
Student Assessment) in 2015 which shows Indonesia can only rank 69 of 76 countries. The survey was conducted by OECD (Organization for Economic Cooperation and Development). OECD is an international organization that embraces free market economy. The OECD survey results are based on test results in 76 countries showing the relationship between education and economic growth. The ranking shows that Indonesia's education quality is still far behind compared to countries in the OECD region.

Actually, there are still many other heartbreaking facts related to the quality of human resources - why the abundant natural wealth is disappointed to the Indonesian nation. Based on some social facts, that the quality of education in Indonesia are still many obstacles and challenges that still can not be resolved. While the quality of education in Indonesia on a macro is determined by millions of institutions named schools.

So the school taking into account the era of globalization that swept the world including Indonesia took place very quickly which led to global too [3], so that the flow of information virtually free in and out of the region of all countries, and difficult to prevent, this can have an impact on Quickly obsolete policy and praxis of education and schooling in Indonesia. Then pay attention to the view of [8] "More than ever to day, the schools do not shut their gates and leave the troubles of the outside world on doorstep. School can no longer pretend that their walls will keep the outside world at bay".

With these challenges, schools need the courage to change. The reform of schools for the excellence of human resources can not be postponed anymore. The implementation of curriculum KTSP or K13 should be an opportunity for public and private schools, to dare to change from the old educational paradigm and displaced by the global era to realize the new things that are currently needed by the community.

Actually the drive to reform and change to adapt new ways or new paradigms has been long enough (several years ago) suggested by some educational experts and practitioners, such as; Speech of the Minister of National Education on May 2, 2002. The reform of the school inevitably has to be done to respond to the worsening educational pattern, so this 
year started the movement to improve the quality of education [10]. Then Mastuhu in [12] explains, that external challenge in education one of them is the era of globalization it is necessary to rearrange the thinking of the national education system. And Sukiyat [13]. Departing from these conditions, our education changes must be reformed ('revolution') fundamentally (mind set actors) on all components in our education system.

From the background of the need for school reform, it should be done to respond to the condition of Indonesian education that is able to condition the school that keeps abreast with the development and the changing times, in addition to the rapid development of the population in need of education services. For that, how the right strategy for education can be enjoyed by all levels of society. This problem required new ideas with school reform. So that will give birth to quality human resources as the key to the success of national development.

\section{PROBLEMS}

Indonesia's human resources will be extraordinary potential, so the key to national development, of course, requires quality education services. Quality education depends on millions of institutions whose names are schools. Then a question arises, How can schools in Indonesia provide quality education at all levels of society through school reform?

\section{PURPOSE}

The purpose of writing this paper, to know and understand the step by step efforts to run school reform, so that school schools in Indonesia are able to provide quality education at all levels of society. By staying on the philosophical foundations of education in Indonesia and relevant to the sociological foundations and juridical foundations in force in Indonesia.

\section{School Reform}

\section{DISCUSSION}

The popular scientific dictionary, explaining reform is changing while improving or improving forms [1]. In this paper, reforms are in the form of strategic execution taking place in a school, ie school management reform related to pupil, community and Relationships with third parties as well as changes to strategic changes that impact on national education policy policies.

\section{Paradigm of Excellence School}

1. Schools become community information centers Schools as social institutions that are held and owned by the public should be able to meet the needs of the community and schools have a legal and formal obligation to provide information to the community about the goals, programs, needs and conditions, and otherwise the school must know clearly what the needs, Hopes and demands of the community (Mamusung in [6].

The opinion is actually, had to bury the old paradigm that the school is just a place to learn from 7 am to $2 \mathrm{pm}$. After that the school became a dark building and did not have any role for the surrounding community. So the school reform can be applied with the idea idea as follows:

a. Quality Time

Schools become the center of information about the problems of community education, especially the guardians of the pupils, today's guardian is in dire need of extensive information about how the right education, especially home-based education, All material is packed in the form of quality time, that is providing information and solutions to guardians How to make quality time in relation to the child. The context is the same as explained by [11] that one type of school and community relationship is the type of educational relationship, the relationship of cooperation between teachers and parents to educate students in the family.

b. Public Library

The school makes its library a public library, which is not only open to its citizens, but also serves the needs of the surrounding community for the needs of books and schools as well as active roles to provide information on new books available in the library. [4] explains the importance of public libraries. Public Library has a very strategic role in improving the living standard of the community, as a vehicle for lifelong learning to develop the potential of the community to become a human being who believes, pious, noble, healthy, knowledgeable, capable, creative, independent, and become citizens of a democratic and responsible Responsible in supporting the implementation of national education, as well as a vehicle for the preservation of the nation's cultural wealth, this is in accordance with the mandated by the 1945 Constitution that is as a vehicle for the intellectual life of the nation.

c. Institute Active Conseling

An active counseling institute is a counseling service provided to learners, teachers, principals, guardians, student families, institutions, communities who need to be able to solve problems encountered. While most of the counseling institutions are just waiting to handle Students are troubled students. This is very unfortunate passive counseling resources.

d. Research of public solution and development

School is an academic and professional research institute about social phenomenon especially related with education problem. Researchers are teachers and can also involve students. In Indonesia, research institutes are only known at the college level. Yet research institutes in primary and secondary schools have never existed, so in school reform there needs to be a research institute in a school school aimed at having students know how to find, interpret and revise facts.

\section{Customer Satisfaction Guarantee}

Napaleon Hill in his book Think \& Rich, explains successful business people relying on customer satisfaction - Napoleon Hill divides the three formulas to serve consumers, Quality, Quantity, and Spirit, the cooperation of the three formulas will result in perfect service - and is recommended to be a 
Customs. Reforms can immediately apply with the following ideas:

a. Quality or quality of service means the appearance of every detail of the education program in the school. May warrant students mastering English in a certain level.

b. Quantity or quantity of service means the ability of the teacher to serve how many students at all times according to the expertise and experience of the teachers.

c. The spirit of school service also means the behavior of pleasant and harmonious behavior, it will encourage cooperation from students, parents, institutions and communities.

School also has Help One Student To Succeed (HOSTS) program is a program prepared by schools to help and guidance against students who do not meet the guarantee - such as not mastering English at the level specified in the warranty. And also HOSTS effectively help students in the field of study which in the process of teaching difficulties.

\section{Teacher Training}

Prof Suyanto. Director General of Education Minister explained in Satria Dharma (2008). Teachers should be invited to change by being trained continuously. Miriam Kronish, primary school principal and also best teacher of the United States, while receiving the Pi Lambda Theta honorary award, his speech sentences, Miriam Kronish, suggested that Master should be trained. Munif Chatib educational consultant, author of his schoolbook of human beings, explained that a superior school is a school that has sufficient training framework. Because teacher training determines whether or not school quality is a quality, schools must have a continuous teacher training program. In the basics of teacher training programs to meet the competencies a teacher must possess.

\section{Process - Teaching and Learning Activities}

Schools assemble attractive learning strategies in the form of fun activities with the distribution of teaching patterns $30 \%$ of teachers make presentations and $70 \%$ of students move to master the taught material. And not tracking - grouping learners based on their cognitive competence. Meaning there is no class of clever children and stupid class of children.

And teachers teach in accordance with student learning styles, and each teacher has an obligation to discover the ability of different children (discovering abilities). The teachers master the learning modalities, because the best learning strategy using learning modalities (visual, Audotorial, Kinesthetic).

Schools need to reform in teaching and learning activities, most of which are Teacher Talking Time - active teacher lectures almost $80 \%$ (learning a doctrine, serious, tense, and teacher-centered), as well as cognitive learning, verbal emphasizing the left brain and passive physically And separate lessons from the application of everyday life. Though learning is nurturing, uplifting and centered on the students applied to everyday life by utilizing the entire brain, multi senses and physically active, because learning can not be done with just one direction. The reason teachers do not necessarily teach students to learn, students are called learning when students do activities.

\section{Assessment}

Schools need to reform the assessment with an authentic assessment model or folio process, the folio process is a process-based assessment related to learning activities during the learning process using portfolios as a tool to summarize or record assessments in three domains, ie cognitive, psychomotoric and affective During the learning process and not at the end of the lesson.

By reforming this scoring system, when schools want to know the student ratings at any time or may be three months, six months or a year of learning, the average method of student competence recorded in the portfolio can be known.

And if the assessment is related to student activity in groups, teachers assess the results of activities in groups. And all students in the group get the same value which is then inserted into the portfolio sheet.

[2] argues that authentic assessment embraces the concept of Ipsantive, that is, the development of student learning outcomes is measured from the student's own development before and after obtaining learning materials. The development of one student should not be compared with the other students. Therefore, authentic judgment does not recognize ranking. With rankings, only the existence of certain students is appreciated, while others do not get the attention of the teacher.

\section{Using Modern Technology}

The use of technology in schools will help students in mastering the learning materials. The technology proposed in school reform is as follows: a). Internet access is an unusual learning resource, b) Movies or VCDs to create instant communication in learning and also to drop memory reinforcement.

\section{New Student Acceptance System (PPDB)}

The New Student Admission System (PPDB) that has been going on for so long needs to be reformed, because it has some disadvantages, that the community is stuck with a paradigm that the superior schools are schools that are strictly screening prospective students and the NEM entry requirements should be high. In this case, the concept of the best input is not the best process. May have an impact on the ordinary teaching and learning process. And the impact of the absence of superior school equity and society stuck on an indicator of a superior school paradigm.

Another disadvantage is that it does not provide educational equity and the test results do not represent the overall intelligence of a child. As Howard [9] points out. Standardized testing using pencil and paper only captures a small sample of intelligence ability and often results in a loss of talent context [9]. Then PPDB yanng lasted for this there is injustice and 
also mental destruction of children as prospective students.

Then the PPDB model does not need to use formal tests to screen students. Prospective learners who register early are accepted immediately, as long as not exceeding the specified limit. With clinical and pathological limitations. (The Zone's PPDB system with the zone system that took place during this school year needs to be maintained.Unfortunately, this year zone system implements the mapping with NEM values and most schools are still through the tests - it may be that the PPDB system through the zone system that goes on this year is a still- half-hearted).

Schools adhere to the concept of The best Process not The Best Input - the intelligence of the nation's children is seen from many dimensions, not only verbal and logical intelligence and schools have the principle that the intelligence of the nation's children is always growing not static. Schools are in the process of discovering the abilities of each prospective student. This means that schools promote the ability and bury the weaknesses of the children of the nation.

Through the reform of the PPDB system it is expected that all the children of the nation can enjoy the same quality of educational quality, as well as equal distribution of education, the loss of tracking (grouping of children based on cognition in some schools). Then the educational practices that occur will build human resources and not kill the potentials of the nation's children.

\section{CONCLUSION}

The movement to improve the quality of education through school reform with superior school design should be done immediately, because the condition of education in Indonesia in a very considerate circumstances in terms of quality and global challenges that must be faced - as current competition by using international quality standards in all aspects of life more real Ranging from products or services, to the everyday lifestyle.

Then the reform of schools with new students' acceptance models - it is seen that rapid population development requires great educational services as well. So how does the education strategy to serve all levels of society equally and fairly mendapakant same education quality, because all children of the nation is a human resource which is the basic capital to utilize natural resources

Which is abundant, for the realization of the vision of national development, namely to make the nation of Indonesia as an independent nation, prosperous, just and prosperous.

By reforming schools to create superior school descriptions and new student acceptance models, issues related to the strength and quality of Indonesian human resources can be answered. Because essentially building a school is the same as building human resources.

\section{REFERENCES}

[1] Albarry, D., M. 2000. Popular Scientific Dictionary, Surabaya: Arkola.

[2] Chatib, M. 2009. The School is Human. Jakarta: Kaifa.

[3] Chatib. M. 2006. Teacher Training YIMI. Gresik

[4] Damono. 2007. School Library: Approach Aspects of Management and Working Procedures, Jakarta: Grasindo.

[5] Darma, S. 2009. From Konkonional Teachers to Professional Teachers, Jakarta: Grasindo.

[6] Aedi, N., and Rosalin, Elin.2011. Education Management: School and Community Cooperation. Bandung Alfabeta.

[7] Farodis, Z. 2011 Education Management Guide a la Harvard University (Virsya Hany, Ed). Jogjakarta: Diva Press.

[8] Hargreaves, A. 1997. RethinkingEducational Change In Michael Fullan (Ed): The Challenge of Scholl Change. Airlington: IRI / Sky Training and Publishing, Inc.

[9] Gardner, H. 2003. Multiple Intellegences: Compound Intelligence Theory and Practice, Batam: Interaksara.

[10] Latief, J., M. 2003. Profile of Religious Teachers in the Context of Competency-Based Curriculum (CBC). Islamic Education, I (1): 29-40.

[11] Purwanto, N. 2008. Administration and Supervision of Education (Tjun Sujarma, Ed.). Bandung: Teens Rosdakarya.

[12] Rahman-Assegaf, A. 2003. Re-Empowering Educators Professionalism: The Perspective of Islamic Education. Islamic Education, I (1): 19-28.

[13] Sukiyat, H. 2010. Indonesian Education Leadership: In the Free Trade Area,: Institute for Scientific Assessment and Development. 